\title{
New Media and the Loss of Individual Sovereignty
}

\section{ManahariAdhikari, Northern Illinois University, USA}

\begin{abstract}
This articleexploresthe impactof new media on authentic existence. It argues that technologyhas reshaped humanity in inconceivable ways,but it is taking away individual sovereignty by facilitating and enhancing power for regimes both democratic and dictatorial.With its design andsophistication thatmakeit possibleto listen in on, record, and funnelcontent produced inthe digital realm to locations of power,new media may lead contemporary society towards an era of centralized control and coercion. The likelihoodof new media beingusedas an instrument of power, a devicefor monitoring themasses, begets an atmosphere of fear, which compromises cognitive habits, inhibitsthe capacity to engage society on a critical level,and givesbirth to a culture of singularity. Withour ontology reconstituted by the technological and with our growing reliance on new media,we are losing our authenticity assovereign individuals.
\end{abstract}

Keywords: (in) authentic existence, identity, monkey mind, singularity, subjectivity, technoregime, and techno-totalitarianism 
In the modern world, the most dangerous form of determinism is the technological phenomenon.

--Jacques Ellul

Discussions of technology within the scholarly community have often focused onthe ease and efficiency new media hasbrought to humanity.Barbara Warnick, for example, admires newmedia for its "affordability, access, opportunities for horizontal communication and interactivity, online forums for discussion and mobilization [and] networking capacity” (6). Echoing these sentiments, Danah Boyd lauds social networks for providing "teens with a space to work out identity and status, make sense of cultural cues, and negotiate public life” (120). And in defense of the shift from print to the digital, Richard Lanham writes, "the sky will not fall as words migrate from page to screen” (155). In this essay I will expand this discussion exploring the effectof technology on authentic existence, albeit from an existential perspective. I argue thatwith the spread of shared knowledge across networks and with new media sedimenting power in the forms of pixels and software,we are becoming prisoners of a modern day penitentiary of technology. ${ }^{2}$ Being perpetually watched and scrutinized begets a culture of fear and influences individual behavior. When fear consumesconsciousness, inquiry is hampered.Technology may soonthreaten our authenticity as sovereign individuals by begetting an era of singularity andby shrinkingthe horizons of the thinking masses. ${ }^{3}$ Moreover, while interfacing with technology, consciousness wanders from one reality to another. Shortened attention spans and decreased mindfulness lead to the hollowing of cognition and the restructuring of neural patterns associated with reflective thinking. When minds wander,

\footnotetext{
1 "New media" refers to media technology as well as technology-based multimedia platforms. Since "digital network," "new media" and "technology" are essentially an operation of the technological, I use them interchangeably.

${ }^{2}$ I use "regime" to refer to a political entity that can search, analyze, and archive content produced in virtual venues such as blogspheres, Twitter, and Facebook. The term refers to both authoritarian and democratic regimes whoretain the power to sift through the digital database and to take punitive measures against people whose views and opinions do not confirm to their own line of thinking.

${ }^{3}$ According to Ray Kurzweil, "one can advance the Singularity and in particular make it more likely to represent a constructive advance of knowledge in many ways and in many spheres of human discourse-for example, democracy, combating totalitarian and fundamentalist belief systems and ideologies" (498). Borrowing from Kurzweil, I use "singularity" to refer to a culture where people live a life of certainty and conformity because they cannot participate fully in the social, cultural, and political spheres for fear of the technological.
} 
neural pathways associated with deep thinking remain inactivated, which hollows out cognition and gives birth to "monkey mind."

In an existential sense, with the advent of New Media, subjectivity is no longer constituted solely of the linguistic but of by digital bytes and pixels as well.According to Katherine Hayles,the "digital subject allows for and indeed demands more drastic fragmentation . . . for it is only when the programs are broken into small pieces and recombined that unexpected adaptive behaviors can arise” (203). Self-construction is dependent ondigital symbology. As much as language, technology supplies the sense of self and shapes individual reality. As a medium that stands in essential relation to us,technology provides enunciative space for the projection of our being. Our lived familiarity with the technological, such as the codes and bytes, makes the iteration of our being possible. The technological becomes a point from which we speak. With signifiers and new media matrices shaping our thinking, subjectivity is already a linguistic as well as a digital phenomenon.

The experience of being is as much a digital event as a linguistic one. Technology affects our understanding of the world, influences our modes of being, and guides our behavior,thus taking on a greater significance in our relations with the world. As a foundation on which subjectivity is based, the digital reconstitutes what has been constituted at the level of language. Just as language, digital provides a platform for the projection of our being. Alexander Reid argues, “Consciousness and materiality are thoroughly atomized in new media and produced as exteriorized simulation. ... New media and simulation constitute the final and complete destruction of the . . cohesive . . . subject of traditional humanism” (789).As Reid describes it, identity formation is a disintegrative process.Only when we appropriate the symbolic as well as the non-phonetic choraof the technological can we comprehend reality. Our identity emerges on the basis of an essential belonging to other new media users.We are virtually embodiedin them.The technological becomes a point of union of camaraderie between us and other new-media users. Users of new media, we become determinants of each other's being. How othersexpress themselves in the networked world determinesour identity andinfluences our desires and actions. In a digito-ontological sense, the certitude that others too appear inside the collaborative space of the technological makes our identity possible. 
Technology captivates us andprovides a sense of coherence and completeness. By relating what we lack to what technology can do for us, we create an ideal state for ourselves. Analogous to the narcissistic relation in which the Lacanian child is with its own image in infancy, we misread the digital manifestation of our being as real. Simulated ontology takes on a greater existential and libidinal significance. KevinRobinscontends, "in the virtual world we shall receive all the gratifications that we are entitled to, but have been deprived of; in this world, we can reclaim that (infantile) illusion of magical creative power" (139). Indeed, the instant gratification technology provides deludes us. Our interface with new mediainducesdesire and it is around the technological that our desire and drive turn. Marshal Sella observes, "given the Net's vast number of unregulated feeds there [is] always the chance that . . . we see sex, rage, unfiltered joy—an accidental moment” (par. 103). We express our frivolities and project our fantasies onto the technological. A point and place of fixation and fulfillment, technologylends a new coherence to our sense of selfand engenders us with a sense of omnipotence that blinds us from technology's coercive nature.

Existence is now such that the linguistic selfis reconstituted inside the realm of technology, an enclosed space of electronic pulses. With our reliance on technology to project our being,we become instruments of its codes and pixels. Digital algorithms limitour ability to be. The forming of our identitywith and through the digitalbears resemblance to the“docile [body that] merely unveils himself to his own eyes in the form of a being who is . . . a living being, an instrument of production, a vehicle for words [and ideas] which exist before him” (Foucault, The Order 313). As we come into beingthrough the digital, we are caught up in a complex web of the technological. We become objects of suspicion and surveillance. Those in positions of powercan access manyfacets of our lives. Situated within the virtual at any point in time and interlocked in the most technical sense through our digital comportment with others, we become targets of, to borrow from Jacques Attali, “eavesdropping, recording and surveillance” (11). With our bodily experiences and our relations to others making their way into the networked environments, our existence is owned.

Identityformationhas nodistinct and inherent nature but it does involve the linguistic as well as the technological. However, with our reliance on the digital, a fundamental problem of existentiality arises. With our“data subject”thrown inside the scopic field of the digital,we are 
no longer sovereign subjects. ${ }^{4}$ Elizabeth Loshfears that "Counters and cookies ... keep track of my visits to the online database .... And regardless of whether or not I choose to leave a comment on the blogs I read, just clicking on the author's profile to verify the credibility of the source . . . . I am producing rhetorical relics” (49).Withaspects of our personal historyleft inside the computational field of the digital, we become subject tosearch andsuspicion. A case in point is the plight ofa "college senior, who was turned down for employment by a prestigious firm on the grounds of his compromising Facebook page"(Losh65). While the student suffereddue to his own actions, his fate reveals the nature of the newpower apparatus, the technological, which makes it possible for regimes tointrude upon peoples' lives. Alice Marwickpoints out that "we all have different sides to our personalities that are expressed more or less in different situations. . . . [o]nsocial media we experience . . . 'context collapse,' in that all these facets are flattened into one” (21).Likewise,while it is difficult to preserve the contexts in which digital views and thoughts are articulated, and also unjust to interpret online views independentfrom authorial intent and the circumstances in which they were expressed and received, governments may ignore these ethical concerns, and transferonline expressions from their larger contextsto artificial ones,imposing their own meaning as indisputable.

What Michael Day recounts in "Teachers at the Crossroads: Evaluating Teaching in Electronic Environments,” for example, helpsexplain the invasive nature of tech-power. In Day’s account, members of the promotion committee "printed and distributed” student works written for a female faculty member "as evidence of lack of involved teaching, even though these were just drafts of student papers” (34), resulting in the denial of her tenure. ${ }^{5}$ What is

\footnotetext{
${ }^{4}$ I borrow the concept "data subject” from Evelyn Ruppert who argues that practices such as the "specific arrangements of humans and technologies ... [as well as] mediations and interactions not only enact populations but also produce subjects” (218). Ruppert writes, “data subject . . . include[s] the practices through which one becomes data through interactions with numerous other actors and actants. Subjectification and enactment must be understood in relation to the configurations and arrangements through which people engage in creating 'themselves.",

${ }^{5}$ Although successful student performance can be indicative of successful teaching, in order to assess the teaching effectiveness of a faculty member more clearly and accurately for promotion and tenure, it is important to compare the level at which students were writing before they took a given course with their level of performance at the end of the course. Were they A, B, C or D level students? What was their attitude toward the use of technology for learning? What technological literacy did they bring to the classroom? Did they come from a conventional or a technology-enhanced classroom? Likewise, the cultivation of good writing skills involves more than a course or two in writing. Students' abilities to explore, to conceptualize, to develop ideas and to put them in writing and the ability to write for different audiences and for various purposes using a wide variety of genre conventions, are all also dependent upon peer relationships; parental engagement; economic status; emotional health of the family; reading, thinking, and writing habits; and the existence of a caring and emotionally intimate community. It is difficult to assess faculty for tenure based solely on the quality of student works. In addition, the use of technology in the teaching of writing is a recent phenomenon and represents
} 
important about this particular episode is that it illustrates how power operates and how new media technologizes power in radically new ways in the digital era. Regardless of where we reside and for what reasons we use technology, the domain of the technological creates conditions for such digital castration.

Thetransmutation of power via technologyreminds usof Foucault's notion of power in traditional societies, particularly his notion of the "optic." According to Foucault, during the classical erapower revolved around high centers such as kings, chiefs, and heads of the families. Given the system, which was hierarchical in nature, people on the top dispensed power and demanded loyalty from those at the bottom. Over time, authoritarian forms of power morphed into different forms. In the modern era, physical punishment has been replaced by "new optics, . . . an organ of generalized and constant oversight, . . . a system of records (with individual files), [an] establishment of a panopticism” (Foucault, Ethics 35). In recent times, the compositional power structure has transmuted into a horizontal one, giving power a new embodiment in the form of software and the interlinked servers of the Internet. Hierarchal systems of power, such as governing bodies, still exist, but with technology working as a monitoring device, we become detainees of the digital, sharingour fate withthat of the inhabitants of Leibniz's Palace of Marvels who live in buildings that are "constructed in such a way that the master of the house [is] able to hear and see everything that is said and done without himself being perceived, by means of mirrors and pipes, which will be a most important thing for the State, and a kind of political confessional” (Attali, 11).Reminiscent of the palace, codes, electronic pulses, and software serve as instruments of surveillance. They record and channelwhat we say without our knowledge to places of power. We may have illusion of choice,liberty, and autonomy,but with the new media the "mechanism of power ... reach into the very grain of individuals, touches their bodies and inserts itself into their action and attitudes” (Foucault, Power 39). William Bogard too observes that "Technologies redouble . . . means of observation. . . . Simulated surveillance is like a Mobius strip, with neither an inside nor an outside surface ... that opens onto endless, nested levels of control, recording, speed traps” (29).

extraordinary challenges both to students andteachers; with the technologizing of reading and writing, some of the force, enthusiasm, and emotion of teaching has been lost. 
During the 1990s,with promising prospects of new-media technology, scholars like Stephen Doheny-Farina had utopian visions of the net:

Governments as we know them are increasingly powerless because nations become irrelevant when communication technologies make borders as porous as air. Power goes to those who can control the flow of information. But when all information, all music, all art, all words, all images, all ideas are digitized, then everyone can access, alter, create, and transmit anything, anywhere, anytime. Welcome to the spectacle. Enter the teeming, buzzing cacophony of cyberspace. The revolution is here. The kings are dead. Long live us all-all virtual citizens in the egalitarian, electronic democracy that is the net. (20-21)

Contrary to what Doheny-Farina had hoped, technology introduced new and expansive possibilities for public control by providing regimes easy access to digital communication at the macro level. With aspects of our ontology etched into the digital ether, dictators have become redundant in our times. The unprecedented access to personal information vastly exceeds what autocratic regimes could have ever imagined.

With aspects of our ontologycaught up in the complex web of digitality, we are gradually becoming pawns in the hands of techno-power. However,scholarly conversationscontinue to characterizetechnology as a tool forauthorship and authenticity. Allan Collins and Richard Halversonargue that "online, people can control what they do, who they communicate with, and even who they are” (5). Invoking Karl Marx, Andrew Sullivan praises blogs,one of the virtual venues, as "a publishing revolution more profound than anything since the printing press"” (par. 7).According to Sullivan, bloggingenableusers to“seize the means of production” and be their own copy editors and publishers (par. 3). For all its ability to bypasses the rituals of the publishing industry, "blogging," Sullivanhopes, "could foment a revolution in how journalism functions” (par. 1). In a similar vein, Carolyn Miller and Dawn Shepherd perceive the blog as a "counter movement to postmodern destabilization" (10). Whereas these accounts emphasize the mere fact of production as a strategy for authorship and power, what is no less significant - perhaps even more so - is the control over the digital code into which the content is carried. 
At this point, I find it useful to recall Georges Bataille’s view of expenditureto elaboratemy argument as to why technology may not be radical unless the public retains holdover the digital data. In "The Notion of Expenditure," Bataille argues that the "consequences in the realm of acquisition are only the unwanted result . . . of a process oriented in the opposite direction” (860). In his brief commentary on Bataille’s theory of expenditure, Hazard Adams argues that, for Bataille, the "fundamental human drive is toward loss. Acquisition is the unwanted result of the process oriented toward loss” (856). Bataille believes that Christianity and bourgeois culture are corrupt because they make all losses useful. While the purpose of giving is noble because it has no other reason than to lose, every loss leads to gain because each sacrifice is made "in the name of charity for the sake of one's soul or in the formalization of giving for some social purpose. The principle of loss must be that of 'unconditional expenditure"” (856).What is rooted at the heart of Christianityand other religions is a paradox, which is, the desire to lose. Such desire, however, is tied to God's favor. In other words,acts of kindnessare entwined with a desire for thesoul's well-being through divine grace.

Paradoxical as it may sound, governmental commitment to investment in and expansion of technologies promotes and legitimizesthe government'spower by discreetly helping to install power at the very personal level. From a Bataillean perspective, the expansion of new information technology and the call for unrestricted access to the Internet serves as an investment in more power. An apparatus for normalizing control, the digital makes it easier to institute powermore democratically. When we trade our personal stories online, we map aspects of our lives onto the digital network. With codes, servers, and software,regimes can collect and archive stories captured inside the technological and use the data for political purposes. With troves of digital data at their fingertips, regimescan study, analyze, and classifyinformation;identify lived experience (such asour online practices); track and determine who we engage and interact withand what we say and read.Regimes can crack the security code of individual laptops, access motherboards, and transfer the information to locations of power for archival and future retrieval. In true Bataillean fashion, the expansion of the Internet seems to be in the public interest but in actuality, grants unlimited power to the regimes. Although the campaign for Internet freedom may seem noble, with technology stratifying power through servers, such advocacyleads to techno-totalitarianism. Thus, authorship and powerare not only about producing and disseminating ideas but arealso about 
retainingpower over what isproduced at networked venues;otherwise, wepurchase our authorship at the expense of our own freedom and authenticity.

Life is a mixture of music and noise, reasonand unreason. Mundane reality involves sanity as well as insanity, sensibility and obscenity. As aspects of our ontology, anger, desire, love,guilt, gratitude, praise, pity, resentment, shame, joy, pain,sobriety, and eccentricity are all essential to our enjoyment of life.But with the technological becoming an existential condition, a new era of fear is born. Neil Richardswrites,"being watched deters us from the kind of free and fearless inquiry on which political and personal freedom depend" (5). Constantly in fear, we become incapable of independent thoughts, let alone produce what I call noise. Here when I say noise, I have the term "chora” in mind, which Julia Kristeva uses to explain pre-syntactic chaos upon which the symbolic order operates. In Kristeva's account, chora is an "amorphous mass, ... . a strange 'space' . . . that arrests and absorbs the motility of the anaclitic facilitations” (Desire283-5). I conceptualize noisealmost in a similar sense as a source of ideas that come to bewhichthe ruling people may label as subversive andthus threatening to their own power. Fearimposes a new procedure for social participation,disciplines individual thought processes, and inhibits thinking. Over time, fear that emanates from the digital can severely impact how we understand our reality and ourselves. We maybecome hesitant to share our lighthearted thoughts and feelings, or to share a laugh. Subjected to fear, the range of our thoughts and opinionsbecome limited.With the suffocation of individual voices, we enter into an era of automated humanity. Fear itself functions as a form of power, a homogenizing one. We begin to live lives of conformity.

We begin to monitor our actions and thoughts and modify our online behavior for fear that the technological can trace what we read, watch, and say online. When fear becomes embedded in our minds, it rules over our thoughts, and forces us to behave according to the logic of the technological. Neil Richards notes, "when we are watched, when we . . . sense that we might be watched, we act differently," which suggests how techno-fear harms our living experiences, if not senses and emotions, and influences how we experience things (4). In a growing atmosphere of fear, we avoid views that challenge the status quo-we begin to act and speak like oneanother. The proliferation of technology produces a thinking effect and influences thinking habits. We begin to self-censor and to monitor our thoughts and online activities. We bear upon ourselves the tyranny of the regime. We fall into an inauthentic mode 
of being. The fear of being watched, if not persecuted, shrinks thinking horizons, limits the range of what we say, and weakens our imaginative potential. Increasingly, the range and variety of our views are limited to the predictable and praised forms preferred by the regimes. With the fear that the regimes can locate, listen to us, and map our subject position, cognitive mechanisms associated with independent and innovative thinking are compromised. Fear leads to homogeneity of thinking and eventually begets a culture of singularity.,On the one hand, like a monkey that leaps through branches without settling at in one place, when we use new media, we monkey around reading texts, looking at images, and surfing the websites. From a neuroscientific perspective, this new habit of mind has significant cognitive implications. With constant division of our attention and the resultant lack of focus, sensory input, and reflection, we fail to put the neural circuitry associated with thinking at work. neurons associated with sustained thinking remain inactive and inflexible when fear impacts how we think and behave. On the other hand, whenfear enters consciousness, it triggers responses in the brain, which may compromise cognitive abilitiesby attenuating, atrophying, or destroying neurological pathways associated with deep thinking.

It follows that, with technology sedimenting power in the forms of sensors and software, theefficacy the digital broughtto our comportment towards the worldmay not be worth celebrating:the ease and efficiencyheralded by the media may not after all represent progress at least not in our capacity for authentic existence.Like never before in history, we are on the verge of facing the existential nightmare of being perpetually watched. With trails of data captured inside the technologicalavailable for harvest—data that explains our mental states, dispositions, and character traits-we are no longer the masters of our own fates. A phenomenon inconceivable in kingly eras, regimes plunder data using software and computer networks, produce their own versions of ourindividual identities, and classify usas subjects of unreasonable search and arrest. With aspects of our experiences trapped inside the actuator and data sensors of technology, we are gradually finding ourselves living in a familiar context, the horrifying existential reality ofLeibniz's Palace of Marvels, the inhabitants ofwhich are tied to mirrors, pipes and tubes. A glimpse of howtechno-power can be turned intoa monitoring device(even by a democratic government)is nowhere more apparent than in the revelations of Edward Snowden. 
Individual sovereignty is tied totheunlimited possibilities of being and existing. Bystepping into the digital domain that captures and carries with it contents associated with our online activities, our individual selvesbecome inauthentic. The issue here is an existential one. If chips and circuits are used to listen in on, order, and transmit online communications for gaugingpersonal history and guessing individualintentions, ancient autocraticregimes areresurrected into a formof techno-totalitarianism. To use software and sensors to watch and collectdigital footprintsin suspicion that each citizen may be a potential suspect and toanalyze and archivethe digital data in a thumb drive is to strip people of their sovereignty. It is to lose moral superiority as a nation that champions individual rights and advocates forindividual sovereignty. More so, it is to cut the very thread with which the authentic psyche of democratic nations has been woven, which is the freedom and sovereignty of all. In using software and sensors to monitor the masses who are fated to live in an inescapable existential condition (such as the necessity to rely on technology for everyday communication), nations may turn into techno-totalitarian states, while their haunting specters that pervade the technological, may turn humanity into automated masses forced to live lives of murderous conformity. Like the Lacanian child who is a pawn of the playful nature of the symbolic (Four, 157),new media usersmay soon become pawns in the hands of techno-power. This frightening possibility of power operating through cell phones and mobile devices, tools and interfaces, and servers and softwarecalls for a fundamental rethinking ofthe use of technology in ways that not only defeat the rogue forces that threaten our freedom and security, but also protect whatdemocratic nations most cherish: the sovereignty of each individual.

Note:

The genesis of this essay lies in a paper I wrote at Northern Illinois University in fall of 2009 for Rhetoric in Digital Composition taught by Prof. Michael Day. He, Gail Jacky, andmy colleague Beth Wheeler provided insightful comments for which I am deeply grateful. 


\section{References}

Adams, Hazard. (1992). Critical Theory Since Plato. Ed. Hazard Adams. Harcourt Brace Jovanovich Press

Attali, Jacques. (1985). Noise: The Political Economy of Music. Trans. Brian Massumi. Minneapolis: $U$ of Minnesota Press

Barthes, Roland. (1973) 1976.The Pleasure of the Text. 1975. London: Jonathan Cape Ltd. Bataille, Georges. (1992). “The Notion of Expenditure.” Critical Theory Since Plato. Ed. Hazard Adams. NY: Harcourt Brace Jovanovich Press.

Bogard, William. (1996). The Simulation of Surveillance: Hypercontrol in Telematic Societies. Cambridge: Cambridge University Press.

Boyd, Danah. (2008). "Why Youth Love Social Network Sites: The Role of Networked Publics in Teenage Social Life.” Youth, Identity, and Digital Media.Ed. David Buckingham. Cambridge, MA: MIT Press.

Collin, Allan and Richard Halverson. (2009). Rethinking Education in the Age of Technology:

The Digital Revolution and Schooling in America. Forward. John Brown. New York: Teachers College Press.

Day, Michael. (2000). “Teachers at the Crossroads: Evaluating Teaching in Electronic

Environments.” Computers and Composition 17, 31-40.

Doheny-Farina, Stephen. (1996). The Wired Neighborhood. New Haven: Yale U Press.

Ellul, Jacques. (1954)1964.The Technological Society.Intro. Robert Merton. Trans. John Wilkinson. New York: Vintage.

Foucault, Michael. (1994). The Order of Things. New York: Vintage.

--. (1994). Ethics Subjectivity and Truth.Ed. Paul Rainbow. Trans. Robert Hurley et.al New York: New Press.

--. (1980). Power/Knowledge: Selected Interviews and Other Writings 1972-77. Ed. Colin Gordon, trans. Gordon et al. New York: Pantheon.

Hayles, Katherine. (2005). My Mother Was a Computer: Digital Subjects and Literary Texts. Chicago: U of Chicago Press.

Kristeva, Julia. (1980). Desire in Language.Ed. Leon S. Roudiez and Trans Thomas Gora, Alice Jardine, and Leon S. Roudiez. New York: Columbia University Press.

--. (1984). Revolution in Poetic Language, trans. Leon S. Roudiez (New York: Columbia University Press. 
Kurzweil, Ray. (2005). The Singularity is Near: When Humans Transcend Biology. New York: Viking.

Lacan, Jacques. Ecrits.(1977) 2007.Trans., Alan Sheridan. New York: Norton.

Richard Lanham. (2007). The Economics of Attention: Style and Substance in the Age of Information. Chicago: University of Chicago Press.

Losh, Elizabeth. (2009). “Hacking Aristotle: What is Digital Rhetoric?” Virtualpolitik: An Electronic History of Government Media-Making in a Time. Massachusetts: MIT Press.

Marwick, Alice E. (April 25, 2014). “In Defense of Getting Personal on Twitter.The Chronicle of Higher Education

Miller, Carolyn and Dawn Shepherd.(2004). "Blogging as Social Action.A Genre Analysis of the Weblog.” Into the Blogosphere: Rhetoric, Community, and Culture of Weblogs. Retrieved February 11, 2015 from $<$ https://conservancy.umn.edu/bitstream/handle/11299/172818/Miller_Blogging\%20as \%20Social\%20Action.pdf?sequence=1\&isAllowed=y>

Reid, Alexander. (2007). The Two Virtuals: New Media and Composition. West Lafayette: Parlor Press.

Richards, Neil. (20 March 2015). “The Electronic Panoptican.”The Chronicle of Higher Education.

Robins, Kevin. (2000). “Cyberspace and the World We Live In.” Cyberspace/Cyberbodies/Cyberpunk: Cultures of Technological Embodiment. Ed. Mike Featherstone and Roger Burrows. London: Sage

Ruppert, Evelyn. (2011) “Population Objects: Interpassive Subjects.” Sociology45(2): 218-33

Sella, Marshall. (2000) “The Electronic Fishbowl.”New York Times Magazine.RetrievedFebruary 24, 2016 from $<$ http://www.nytimes.com/2000/05/21/magazine/the-electronicfishbowl.html?pagewanted=all>

Sullivan, Andrew. (2002). “The Blogging Revolution: Weblogs are to Words What Napster was to Music.” Retrieved March 15, 2014 from $<$ http://archive.wired.com/wired/archive/10.05/mustread.html?pg=2/>

Warnick, Barbara. (2007). Rhetoric Online. New York: Peter Lang. 